\title{
Vital Signs Changes of Brick Industry Workers Exposed to Heat Pressure in Sukarami Palembang
}

\section{Syokumawena Syokumawena*, Marta Pastari*, Rahmad A. Juliansyah*, Hanna S.W. Kusuma ${ }^{* *}$, Dwi D. Rihibiha***}

\author{
*Nursing Study Program, State Polytechnic of Health Palembang, \\ Jl. Sukabangun I No.1159 Palembang, South Sumatera, Indonesia \\ ${ }^{* *}$ Aretha Medika Utama, Biomolecular and Biomedical Research Center, \\ Jl. Babakan Jeruk II No.9, Bandung, West Java, Indonesia \\ Email: hannasariwidyaa@gmail.com
}

\begin{abstract}
Brick workers are exposed to dust contained of mixtures of chemical substances and high temperature. Those environmental factors can affect the health status of the workers; mainly the cardiovascular system. The aim of this research was to observe the effect of heat pressure on vital sign of brick factory manufacturing workers in Sukarami Palembang. The research was conducted in RT 07/13 Sungai Durian, Kecamatan Sukarami, Palembang. The subjects were 40 people brick workers; 20 workers were exposed to heat pressure and 20 workers did not. We found that in the workers with heat pressure exposure, the average vital signs before working are blood pressure of $117 / 76 \mathrm{mmHg}$, pulse of $77 \mathrm{x} / \mathrm{minutes}$, and body temperature of $36,5^{\circ} \mathrm{C}$ and after working are blood pressure of 130/84 $\mathrm{mmHg}$, pulse of 92 $x /$ minutes, and body temperature of $38^{\circ} \mathrm{C}$. In the workers without heat pressure exposure, the average vital signs before working are blood pressure of 107/80 $\mathrm{mmHg}$, pulse of $75 \mathrm{x} /$ minutes, and body temperature of $36^{\circ} \mathrm{C}$ and the average vital signs after working are blood pressure of $112 / 81 \mathrm{mmHg}$, pulse of $79 \mathrm{x} /$ minutes, and body temperature of $37^{\circ} \mathrm{C}$. Conclusion, heat pressure has effects on vital sign of brick factory manufacturing workers in Sukarami Palembang.
\end{abstract}

Keywords: blood pressure, body temperature, brick factory pulse, heat pressure 


\title{
Perubahan Tanda Vital pada Pekerja Industri Pabrik Pembuatan Batu Bata dengan Paparan Tekanan Panas di Kecamatan Sukarami Kota Palembang
}

\author{
Syokumawena Syokumawena*, Marta Pastari", Rahmad A. Juliansyah", \\ Hanna S. W. Kusuma ${ }^{* *}$, Dwi D. Rihibiha** \\ *Program Studi Keperawatan Politeknik Kesehatan Palemban \\ Jl. Sukabangun I No.1159 Palembang, Sumatera Selatan, Indonesia \\ ** Aretha Medika Utama, Biomolecular and Biomedical Research Center \\ J1. Babakan Jeruk II No.9, Bandung, Jawa Barat, Indonesia \\ Email: hannasariwidyaa@gmail.com
}

\begin{abstract}
Abstrak
Pekerja batu bata bekerja dengan aktivitas yang beragam dan secara langsung dapat terpapar debu yang mengandung campuran bahan kimia dan suhu tinggi. Lingkungan tersebut dapat mempengaruhi status kesehatan pekerja terutama pada sistem kardiovaskular. Penelitian ini bertujuan untuk mengetahui apakah tekanan panas menyebabkan perubahan tanda vital pada pekerja industri pabrik pembuatan batu bata di Kecamatan Sukarami, Palembang. Subjek penelitian adalah 40 orang pekerja pembuat batu bata; 20 orang pekerja terpapar tekanan panas dan 20 orang pekerja tidak. Kami mendapatkan bahwa pada kelompok yang mendapatkan tekanan panas, rerata tanda vital pekerja sebelum terpapar tekanan panas adalah tekanan darah $117 / 76 \mathrm{mmHg}$, nadi $77 \mathrm{x} /$ minutes, dan suhu tubuh $36,5^{\circ} \mathrm{C}$ dan setelah terpapar tekanan panas adalah tekanan darah $130 / 84 \mathrm{mmHg}$, nadi $92 \mathrm{x} /$ minutes, dan suhu tubuh $38^{\circ} \mathrm{C}$. Pada kelompok yang tidak terpapar tekanan panas, rerata tanda vital pekerja sebelum bekerja adalah tekanan darah 107/80 $\mathrm{mmHg}$, nadi $75 \mathrm{x} /$ minutes, dan suhu tubuh $36^{\circ} \mathrm{C}$ dan setelah bekerja adalah tekanan darah 112/81 mmHg, nadi $79 \mathrm{x} /$ minutes, dan suhu tubuh $37^{\circ} \mathrm{C}$. Simpulan, tekanan panas menyebabkan perubahan tanda vital para pekerja pabrik industri pembuatan batu bata di Kecamatan Sukarami, Palembang.
\end{abstract}

Kata kunci: suhu tubuh, tekanan darah, nadi, tekanan panas, pabrik batu bata 
Research Article

\section{Pendahuluan}

Kota Palembang merupakan salah satu kota yang banyak terdapat industri bedeng pembuatan batu bata. Di Kelurahan Alang-alang Lebar Kecamatan Sukarami terdapat sekitar 140 bedeng aktif yang memproduksi batu bata dengan masing-masing terdapat 40 orang pekerja di setiap bedeng dengan pembagian tugas sebagai pencetak dan penyusun batu bata serta pembakar batu bata. Penelitian Donoghue dan Bates pada pekerja tambang besi bawah tanah di Australia, dengan rentang suhu basah, kering, dan bola (ISBB) 26,0-28,0 ${ }^{\circ} \mathrm{C}$, ditemukan sebanyak 65 kasus acute heat exhaustion. ${ }^{1}$ Adapun penelitian yang dilakukan oleh Krisanti pada pekerja bagian produksi sebuah CV di Surakarta yang menyatakan adanya hubungan tekanan panas dengan kelelahan kerja. Paparan panas dapat pula menyebabkan keluhan lain selain pengeluaran keringat berlebih dan perasaan cepat lelah. ${ }^{1}$ Adapun menurut Stohr dkk. (2011) dan Fehling dkk. (2015), paparan panas serta dehidrasi juga mempengaruhi sistem kardiovaskular sehingga menyebabkan penurunan kualitas kinerja, efisiensi, dan produksi., ${ }^{2,3}$

Penyakit yang biasa timbul akibat panas adalah penyakit jantung, tekanan darah tinggi, gangguan ginjal, dan gangguan psikiatri. Penyakit akibat terpaan panas ini diakibatkan karena naik atau turunnya suhu tubuh. Suhu normal tubuh berkisar antara $36,4-37,2^{\circ} \mathrm{C}\left(97,5-99,0^{\circ} \mathrm{F}\right)$. Perubahan suhu inti tubuh naik/turun $2^{\circ} \mathrm{C}$ dapat mengakibatkan gangguan pada tubuh, dan suhu nikmat kerja berkisar antara $24^{\circ} \mathrm{C}-26^{\circ} \mathrm{C}$ bagi orang Indonesia. Orang Indonesia pada umumnya beraklimatisasi dengan iklim tropis yang suhunya sekitar $29^{\circ} \mathrm{C}-30^{\circ} \mathrm{C}$ dengan kelembaban $85 \%$ $95 \%{ }^{4}$

Menurut Sherwood (2014), penyakit yang biasa timbul akibat panas adalah penyakit jantung, tekanan darah tinggi, gangguan ginjal dan gangguan psikiatri. Penyakit akibat terpaan panas ini diakibatkan karena naik atau turunnya suhu tubuh. Suhu normal tubuh berkisar antara $36,4-37,2^{\circ} \mathrm{C}\left(97.5-99.0^{\circ} \mathrm{F}\right) .{ }^{4}$ Nilai normal denyut nadi pada orang dewasa adalah $60-80 \mathrm{x} / \mathrm{menit}$, jika pengukuran dilakukan setelah bekerja, maka nadi normal pekerja tersebut adalah 90 kali/menit. ${ }^{4}$ Jika denyut nadi melebihi 90 kali/menit setelah 5 menit melakukan pekerjaan, diperkirakan tekanan panas di lingkungan kerja berlebihan.

Tekanan darah sangat bervariasi tergantung pada keadaan, akan meningkat saat aktivitas fisik, emosi dan stres. Semakin tinggi tekanan darah akan semakin besar risikonya dan jika tekanan darah lebih dari $160 / 90 \mathrm{mmHg}$ akan memiliki faktor risiko penyakit jantung. Rerata nilai normal pemeriksaan tekanan darah pada orang dewasa adalah $120 / 80 \mathrm{mmHg}{ }^{5}$

Pada para pekerja di bedeng batu bata ini belum pernah dilakukan pemeriksaan tekanan darah, nadi, maupun suhu selama bekerja. Penelitian tentang efek fisiologis pada pekerja industri pembuatan batu bata di Kota Palembang juga belum pernah dilakukan sebelumnya. 


\section{Research Article}

Berdasarkan hal tersebut di atas, maka peneliti tertarik untuk meneliti pengaruh tekanan panas terhadap efek fisiologi pada pekerja industri pembuatan batu bata di Kecamatan Sukarami Kota Palembang.

Tekanan panas (heat stress) adalah beban iklim kerja yang diterima oleh tubuh manusia. Suhu udara dapat diukur dengan termometer biasa (termometer suhu kering). Kelembaban udara diukur dengan menggunakan hygrometer. Suhu dan kelembaban dapat diukur bersama-sama dengan misalnya menggunakan alat pengukur sling psychrometer atau arsman psychrometer yang juga menunjukkan suhu basah sekaligus. ${ }^{6}$

Pada kondisi dengan tekanan panas, diperlukan upaya tambahan pada anggota tubuh untuk memelihara keseimbangan suhu tubuh. Menurut Adisasmito (2014), reaksi fisiologis tubuh (heat strain) oleh karena peningkatan temperatur udara di luar comfort zone adalah pada kondisi vasodilatasi, denyut jantung meningkat, temperatur kulit meningkat, suhu inti tubuh pada awalnya turun kemudian meningkat, serta paparan panas yang terus berlanjut sehingga mengakibatkan gangguan kesehatan. ${ }^{7}$

Nilai ambang batas iklim kerja indeks suhu basah, kering, dan bola (ISBB) yang diperkenankan oleh Menteri Tenaga Kerja dan Transmigrasi Republik Indonesia NOMOR PER.13/MEN/X/2011 tentang Nilai Ambang Batas Faktor Fisika dan Faktor Kimia di Tempat Kerja dapat dilihat pada Tabel 1.

\section{Tabel 1 Nilai Ambang Batas Iklim Kerja}

\begin{tabular}{|c|c|c|c|c|}
\hline \multirow{3}{*}{$\begin{array}{c}\text { Pengaturan } \\
\text { Waktu Kerja } \\
\text { Setiap Jam }\end{array}$} & \multirow{3}{*}{$\begin{array}{l}\text { Pengaturan Waktu } \\
\text { Istirahat }\end{array}$} & \multicolumn{3}{|c|}{ ISBB $\left({ }^{\circ} \mathrm{C}\right)$} \\
\hline & & \multicolumn{3}{|c|}{ Beban Kerja* } \\
\hline & & Ringan & Sedang & Berat \\
\hline $75 \%-100 \%$ & $25 \%$ & 31.0 & 28.0 & - \\
\hline $50 \%-75 \%$ & $50 \%$ & 31.0 & 29.0 & 27.5 \\
\hline $25 \%-50 \%$ & $25 \%$ & 32.2 & 30.0 & 29.0 \\
\hline $0 \%-25 \%$ & $0 \%$ & 32.2 & 31.1 & 30.5 \\
\hline
\end{tabular}

Ket: ISBB (indeks suhu basah, kering, dan bola) *Beban kerja ringan (kebutuhan kalori sampai dengan 200 Kilo kalori/jam), beban kerja sedang (kebutuhan kalori >200 - <350 Kilo kalori/jam), beban kerja berat (kebutuhan kalori >350 - >500 Kilo Kalori/Jam)

Tekanan darah mempunyai dua komponen: sistolik dan diastolik. Tekanan darah sistolik menggambarkan tekanan maksimum pada arteri ketika kontraksi ventrikel kiri atau sistol dan diatur oleh volume stroke (atau volume darah yang dipompa keluar pada setiap denyut jantung). Tekanan darah diastolik adalah tekanan saat istirahat yaitu tekanan dari darah antar kontraksi ventrikel. Tekanan darah dibuat dengan mengambil dua ukuran dan biasanya diukur seperti berikut; $120 / 80 \mathrm{mmHg}{ }^{8}$ 
Research Article

Menurut Sherwood (2014) denyut nadi optimal tenaga kerja tergantung saat kapan mengukur denyut nadi. Jika pengukuran dilakukan setelah bekerja, maka nadi normal pekerja tersebut adalah 90 denyut/menit. Jika denyut nadi melebihi 90 denyut/menit setelah 5 menit melakukan pekerjaannya, maka dapat disimpulkan bahwa tekanan panas di lingkungan kerja mungkin telah berlebihan dan oleh karenanya perlu dilakukan evaluasi terhadap lingkungan tempat kerja. Menurut Suma'mur (2014) kategori beban kerja berdasarkan denyut nadi kerja dibagi atas beban kerja sangat ringan, ringan, sedang, berat, sangat berat dan sangat berat sekali. Kategori sangat ringan jika $>75 \mathrm{kali} / \mathrm{menit}$, ringan 75-100 kali/menit, sedang 100-125 kali/menit, berat 125-150 kali/menit, sangat berat 150-175 kali/menit, sangat berat sekali >175 kali/menit. $^{6}$

Respons fisiologis akan nampak jelas terhadap pekerja dengan iklim kerja panas berupa peningkatan tekanan darah dan denyut nadi seperti hasil penelitian yang menyatakan bahwa terdapat perbedaan peningkatan tekanan darah yang signifikan pada tenaga kerja sebelum dan sesudah terpapar panas, yang jelas sekali akan memperburuk kondisi pekerja. ${ }^{8}$

Menurut Pearce (2011) pada peningkatan temperatur udara di luar comfort zone akan timbul reaksi fisiologis tubuh (heat strain) berupa vasodilatasi, peningkatan denyut jantung, peningkatan temperatur kulit, penurunan suhu inti tubuh yang kemudian diikuti peningkatannya ${ }^{8}$ Jika suhu lingkungan meningkat, maka efek fisiologis yang terjadi adalah terjadinya peningkatan kelelahan, denyut jantung, tekanan darah, aliran darah melalui kulit, penurunan aktivitas organ pencernaan, sedikit peningkatan suhu inti dan peningkatan tajam suhu shell (suhu kulit akan naik dari $32^{\circ} \mathrm{C}$ ke $36-37^{\circ} \mathrm{C}$ ), serta dapat meningkatkan produksi keringat yang menjadi berlebihan jika suhu kulit mencapai $34^{\circ} \mathrm{C}$ atau lebih. ${ }^{8}$

Pabrik pembuatan bata bata merupakan suatu usaha yang memproduksi batu bata. Batu bata adalah bahan bangunan yang telah lama dikenal dan dipakai oleh masyarakat baik di pedesaan maupun di perkotaan yang berfungsi untuk bahan bangunan konstruksi. Hal ini dapat dilihat dari banyaknya pabrik batu bata. Berdasarkan studi pendahuluan yang dilakukan peneliti, di Kota Palembang terdapat banyak industri/bedeng pembuatan batu bata yang berpusat di Kelurahan Alang-alang Lebar Kecamatan Sukarami yang berjumlah 140 bedeng aktif dengan masing-masing terdapat 40 orang pekerja di setiap bedeng dengan pembagian tugas sebagai pencetak dan penyusun batu bata serta pembakar batu bata.

\section{Metode}

Penelitian ini bersifat deskriptif observasional, dengan pemeriksaan terhadap tekanan darah, nadi, dan suhu tubuh pada pekerja yang terpapar tekanan panas dan tidak. Penelitian 
Research Article

dilaksanakan di Bedeng Pembuatan Batu Bata RT 07 Sungai Durian Kecamatan Sukarami Kelurahan Talang Betutu Palembang. Pengambilan data penelitian dilakukan pada bulan September-November 2016. Populasi penelitian berjumlah 40 orang yang merupakan pekerja pembuat batu bata; 20 subjek dengan paparan tekanan panas dan 20 subjek tanpa paparan tekanan panas. Kriteria inklusi penelitian ini adalah pekerja industri pembuatan batu bata, jam kerja efektif 8 jam per hari, bersedia menjadi responden dalam penelitian, pekerja yang berusia antara 20-35 tahun, serta pekerja yang memiliki masa kerja lebih dari 1 tahun.

Penelitian ini dilakukan berdasarkan persetujuan melalui informed consent yang telah ditandatangani oleh pekerja di Pabrik Pembuatan Batu Bata di Kecamatan Sukarami, Kota Palembang Tahun 2016 yang merupakan sampel dalam penelitian ini. Peneliti melakukan pemeriksaan tekanan panas pada lingkungan kerja dan pemeriksaan tanda-tanda vital (tekanan darah, suhu dan nadi) pada pekerja pada jam 08.00 (sebelum bekerja) dan jam 16.00 (setelah/pulang kerja). Penelitian ini sudah disetujui oleh Komisi Etik Penelitian Kesehatan Politeknik Kesehatan Makassar No 296/KEPK-PTKMKS/X/2016.

\section{Hasil}

Berikut ini merupakan rata-rata kondisi fisiologis pekerja selama 3 hari sebelum dan setelah bekerja di bedeng pabrik pembuatan batu bata. Hasil pengukuran kondisi fisiologis (tekanan darah, denyut nadi dan suhu tubuh) para pekerja yang ditampilkan pada tabel merupakan rerata nilai baik pada kelompok kontrol maupun kelompok pekerja (Tabel 2).

Tabel 2 Rerata Kondisi Fisiologis Pekerja Sebelum dan Setelah Bekerja

\begin{tabular}{lcccc}
\hline \multirow{2}{*}{ Parameter } & \multicolumn{2}{c}{ Kelompok Tanpa Paparan } & \multicolumn{2}{c}{ Kelompok Dengan Paparan } \\
\cline { 2 - 5 } & Sebelum bekerja & Setelah bekerja & Sebelum bekerja & Setelah bekerja \\
\hline Tekanan darah & $107 / 80 \mathrm{mmHg}$ & $112 / 81 \mathrm{mmHg}$ & $117 / 76 \mathrm{mmHg}$ & $130 / 84 \mathrm{mmHg}$ \\
Denyut nadi & $75 / \mathrm{menit}$ & $79 /$ menit & $77 / \mathrm{menit}$ & $92 / \mathrm{menit}$ \\
Suhu tubuh & $36^{\circ} \mathrm{C}$ & $37^{\circ} \mathrm{C}$ & $36.5^{\circ} \mathrm{C}$ & $38^{\circ} \mathrm{C}$ \\
Tekanan panas & \multicolumn{2}{c}{$27.5^{\circ} \mathrm{C}$} & & $46^{\circ} \mathrm{C}$ \\
\hline
\end{tabular}

Berdasarkan Tabel 2 di atas terlihat bahwa pada kondisi fisiologis pekerja yang meliputi tekanan darah, denyut nadi, suhu tubuh dan tekanan panas terjadi peningkatan pada kelompok dengan paparan tekanan panas jika dibandingkan dengan yang tidak. 
Research Article

\section{Diskusi}

Paparan panas dan bekerja dengan intensitas tinggi secara terus-menerus dapat menyebabkan kelelahan, keletihan, dan menurunkan produktivitas. Pola kerja demikian dapat kita temukan salah satunya pada industri pabrik pembuatan batu bata tradisional dan harus diturunkan untuk mengurangi produksi panas tubuh, ketegangan jantung, dan kelelahan panas. ${ }^{9}$

American Conference of Gorvernmental Industrial Hygienists menyebutkan bahwa batas suhu lingkungan bagi para pekerja adalah $32,2^{\circ} \mathrm{C}$ untuk pekerjaan ringan, $31,1^{\circ} \mathrm{C}$ untuk pekerjaan sedang, dan $30,0^{\circ} \mathrm{C}$ untuk pekerjaan yang berat. Meski demikian nilai paparan ambang batas ini threshold exposure values (TLVs) diasumsikan bahwa para pekerja sudah diaklimatis, mengenakan pakaian, dan mendapatkan air dan asupan garam yang cukup. ${ }^{9,10}$ Pada bedeng yang menjadi subjek penelitian di Kecamatan Sukarami, Kota Palembang tidak ditemukan adanya manajemen pemeliharaan unit dan pekerja seperti rehidrasi pada musim kemarau dan aklimatisasi pekerja.

Menurut Arif (2012) tekanan darah adalah desakan darah terhadap dinding-dinding arteri ketika darah tersebut dipompa dari jantung ke jaringan. ${ }^{11}$ Peningkatan atau penurunan tekanan darah akan memengaruhi homeostatis di dalam tubuh. ${ }^{12}$ Tekanan darah berubah-ubah sepanjang hari, sesuai dengan situasi. Tekanan darah meningkat dalam keadaan gembira, cemas, atau sewaktu melakukan aktivitas fisik. Tekanan darah dapat kembali normal seiring dengan menurunnya beban kerja atau seiring dengan semakin relaks seseorang. Terdapat dua macam kelainan tekanan darah, antara lain hipertensi atau tekanan darah tinggi dan hipotensi atau tekanan darah rendah. ${ }^{12}$ Adapun klasifikasi tekanan darah menurut JNC VII. Kategori normal adalah $\leq$ 120/80mmHg, pre-hipertensi 120-139/80-89mmHg, hipertensi derajat I 140-159/90$99 \mathrm{mmHg}$, hipertensi derajat II $\geq 160 / 100 \mathrm{mmHg}$.

Pada hasil terjadi perbedaan perubahan denyut nadi disebabkan karena terdapat perbedaan pembagian tugas dalam proses industri batu bata, seperti terdapat beberapa pekerja yang bertugas dalam proses pembakaran batu bata di tungku pembakaran sedangkan pekerja lainnya hanya bertugas pada saat pencetakan dan penyusunan batu bata sehingga para pekerja yang tidak berhadapan langsung dengan tungku pembakaran frekuensi denyut nadinya normal dibandingkan dengan pekerja yang berhadapan dengan tungku pembakaran. ${ }^{13}$

Pada kelompok tanpa paparan tekanan panas didapatkan rata-rata suhu tubuh sebelum bekerja adalah sebesar $36^{\circ} \mathrm{C}$ dan sesudah bekerja adalah sebesar $37^{\circ} \mathrm{C}$ (Suhu Tubuh Normal = $36,4-37,2^{\circ} \mathrm{C}$ ). Pada kelompok dengan paparan tekanan panas didapatkan rata-rata suhu tubuh sebelum bekerja adalah sebesar $36,5^{\circ} \mathrm{C}$ dan sesudah bekerja adalah sebesar $38^{\circ} \mathrm{C}$. Menurut Haditia (2012), bila tubuh pekerja terpapar tekanan panas secara langsung yang berasal dari 


\section{Research Article}

tungku pembakaran, maka pekerja akan mengeluarkan keringat yang berlebihan karena tekanan panas dapat meningkatkan kinerja jantung untuk mengalirkan darah ke kulit serta meningkatkan penguapan keringat dalam rangka mempertahankan suhu tubuh. ${ }^{5}$

Rerata tekanan panas yang diterima oleh kelompok tanpa paparan tekanan panas masih dalam rentang nilai ambang batas suhu ruangan/NAB (NAB Suhu Ruangan Normal $=25.9$ $30.6^{\circ} \mathrm{C}$ ), sedangkan pada kelompok dengan paparan tekanan panas didapatkan rata-rata suhu ruangan yang diterima oleh kelompok perlakuan adalah sudah berada di atas rentang nilai ambang batas suhu ruangan/NAB.

Peraturan Menteri Tenaga Kerja dan Transmigrasi Nomor Per.13/Men/X/2011 Tahun 2011 mengenai Nilai Ambang Batas Faktor Fisika di Tempat Kerja dengan pengaturan waktu kerja $75 \%$ kerja dan 25\% istirahat untuk 8 jam kerja dengan beban kerja ringan, Nilai Ambang Batas (NAB) di tempat kerja tersebut adalah $31,0^{\circ} \mathrm{C}$. Pada penelitian ini tekanan panas yang diterima oleh kelompok dengan paparan tekanan panas sudah berada di atas rentang nilai ambang batas suhu ruangan/NAB, yaitu $43,5-47,5^{\circ} \mathrm{C} .{ }^{11}$

Penelitian yang dilakukan Siska dan Teza (2012) menyatakan bahwa peningkatan denyut nadi dapat juga disebabkan karena pekerja membakar batu bata di depan tungku secara manual menggunakan kayu sehingga otot-otot tangan menegang. Hal lainnya disebabkan juga karena pakaian yang digunakan oleh pekerja pembakar batu bata kebanyakan menggunakan kaus yang bahan dasarnya terbuat dari bahan tetoron. Bahan ini terasa panas di badan dan kurang bisa menyerap keringat, sehingga pekerja akan lebih merasa panas dengan pakaian yang kurang nyaman. ${ }^{14}$

Menurut Dewi et al. (2012) peningkatan tekanan sistolik tanpa diikuti oleh peninggian tekanan diastolik disebut hipertensi sistolik atau hipertensi sistolik terisolasi (isolated systolic hypertension). Kriteria hipertensi sistolik terisolasi adalah bila peningkatan tekanan sistolik lebih besar dari 2 kali tekanan diastolik dikurangi $15 \mathrm{mmHg}$, tanpa diikuti oleh peninggian tekanan diastolik, atau tekanan sistolik lebih dari 2 kali tekanan diastolik, bila tekanan diastolik tidak melebihi $90 \mathrm{mmhg}$. Hipertensi sistolik terisolasi adalah peninggian tekanan darah sistolik tanpa diikuti oleh peningkatan tekanan darah diastolik, biasanya sering ditemukan pada golongan lanjut usia (di atas 60 tahun). ${ }^{15}$

Tekanan panas disebabkan karena adanya sumber panas yang mempengaruhi kondisi lingkungan kerja. Intensitas panas cenderung meningkat yang mengakibatkan peningkatan tekanan darah, denyut nadi dan penurunan respons kulit. ${ }^{16}$ Penelitian ini sejalan dengan penelitian lain yang menyatakan bahwa pekerja yang bekerja di lingkungan panas akan mengalami indikator heat strain yaitu peningkatan denyut nadi, tekanan darah, suhu tubuh serta 


\section{Research Article}

pengeluaran keringat dimana respons-respons fisiologis akan meningkat pada pekerja dengan iklim kerja yang panas, sehingga dapat memperburuk kondisi pekerja. ${ }^{16}$

\section{Simpulan}

Tekanan panas menyebabkan perubahan tanda vital para pekerja pabrik industri pembuatan batu bata di Kecamatan Sukarami, Kota Palembang.

\section{Ucapan Terima Kasih}

Penulis mengucapkan terima kasih kepada drg. Nur Adiba Hanum, M. Kes. (Direktur Poltekkes Kemenkes Palembang), Budi Santoso, M.Kep., Sp.Kom., (Ka. Jurusan Keperawatan Poltekkes Kemenkes Palembang), Jhon Feri, S.Kep., Ners., M.Kes., (Ka. Prodi Keperawatan Lubuk linggau Poltekkes Kemenkes Palembang), Rudy Hartono, SKM., M.Kes. (Chairman Komisi Etik Penelitian Kesehatan Politeknik Kesehatan Makassar), serta kepada seluruh pemilik dan pekerja bedeng industri batu bata di RT 07 RW. 13 Kel. Talang Betutu Kecamatan Sukarami Kota Palembang.

\section{Daftar Pustaka}

1. Indra I, Naiem M, Wahyuni A. Determinan keluhan akibat tekanan panas pada pekerja bagian dapur rumah sakit di kota Makassar. Jurnal Kesehatan Masyarakat. 2014:1-10.

2. Stohr EJ, González-Alonso J, Pearson J, Low DA, Ali L, Barker H, Shave R. Dehydration reduces left ventricular filling at rest and during exercise independent of twist mechanics. J Appl Physiol. 2011;111(3):89197.

3. Fehling PC, Haller JM, Lefferts WK, Hultquist EM, Wharton M, Rowland TW, Smith DL. Effect of exercise, heat stress and dehydration on myocardial performance. Occup Med. 2015; 65(4):317-23.

4. Sherwood L. Fisiologi manusia dari sel ke sistem. Edisi 6. Jakarta: EGC; 2014.

5. Haditia I. Analisis pengaruh suhu tinggi lingkungan dan beban kerja terhadap konsentrasi pekerja. Jakarta: Fakultas Teknik Universitas Indonesia; 2012. (Repository)

6. Suma'mur S. Kesehatan kerja dalam perspektif hiperkes dan keselamatan kerja. Jakarta: Erlangga; 2014.

7. Adisasmito W. Sistem kesehatan. Yogyakarta: Raja Grafindo; 2014.

8. Pearce E. Anatomi dan fisiologi untuk paramedis. Jakarta: PT Gramedia Pustaka Utama; 2011.

9. Sett M, Subhashis S. Effects of occupational heat exposure on female brick workers in West Bengal, India. Glob Health Action. 2014;7(21923):1-11.

10. Parsons K. Occupational health impacts of climate change: current and future ISO standards for the assessment of heat stress. Ind Health. 2013;51(1):86-100.

11. Atmaja A, Wijaya R, Qodrijati I. Laporan Akhir: Hubungan antara iklim kerja panas dengan tingkat dehidrasi pada tenaga kerja di unit kantin PT. Indoacidatama. tbk. Kemiri Kebakramat, Karanganyar. Surakarta; Fakultas Kedokteran, Universitas Sebelas Maret Surakarta; 2012. (Repository)

12. Anggara F, Nanang P. Faktor-faktor yang berhubungan dengan tekanan darah di Puskesmas Telaga Murni, Cikarang Barat Tahun 2012. Jurnal Ilmiah Kesehatan. 2013;5(1):20-5.

13. Kau A. Hubungan antara tingkat tekanan panas dengan frekuensi denyut nadi pekerja pandai besi di kelurahan Padebuolo, Gorontalo. Gorontalo: Jurusan Kesehatan Masyarakat, Fakultas Ilmu-ilmu Kesehatan dan. Keolahragaan, Universitas Negeri Gorontalo; 2014. (Repository)

14. Siska M, Teza M. Analisa posisi kerja pada proses pencetakan batu bata menggunakan metode NIOSH. Jurnal Ilmiah Teknik Industri. 2012;11(1):61-70.

15. Dewi E, Novita L, Susanti A. Pengaruh suhu udara ruang kerja terhadap perubahan tekanan darah sebelum dan sesudah bekerja pada pekerja unit hot press PT. Primarindo Asia Infrastructure. TBK. Bandung Tahun 2012. Bhakti Kencana Medika. 2012;2(6):285-90.

16. Arfad F, Sinaga M, Silaban G. Perbedaan tekanan darah sebelum dan sesudah terpapar panas pada pekerja bagian bottling process PT Sinar Sosro Deli Serdang Tahun 2013. Lingkungan dan Kesehatan Kerja. 2013;3(1):1-8. 